JJTM, Vol. 5 No. 3, November 2017

\title{
ANALISA TEGANGAN STATIK PADA PENGEMBANGAN DESAIN COVER CVT PADA RANCANGAN KENDARAAN ELECTRIC VEHICLES GANESHA 1.0 GENERASI 1 BERBANTUANSOFTWARE ANSYS 14.5
}

\author{
M.Hari Krisnayadi ${ }^{1}$, K. Rihendra Dantes ${ }^{2}$,I.N Pasek Nugraha ${ }^{3}$ \\ 1,2,3 Jurusan Pendidikan Teknik Mesin \\ Universitas Pendidikan Ganesha
}

Email : harikrisna@yahoo.com ${ }^{1}$, rihendra79@gmail.com², paseknugraha@undiksha.ac.id ${ }^{3}$

\begin{abstract}
Abstrak
Cover CVT merupakan komponen yang memiliki peran penting dari sepeda motor metic karena memiliki fungsi melindungi komponen-komponen CVT dari benturan, kotoran, air ataupun benda-benda yang dapat merusak komponen-komponen CVT. Maka dari itu, dilakukan analisis tegangan static pada desain cover CVT pada rancangan kendaran electric vehicles ganesha 1.0 generasi 1 yang menggunakan cover CVT Yamaha nuvo sebagai bahan pengembangan desain cover CVT dengan menggunakan software ansys 14.5 dengan perbandingan pembebanan maksimal sebesar $75 \mathrm{~kg}$ dan pembebanan awal sebesar $5 \mathrm{~kg}$. Tujuan penelitian adalah untuk mengetahui distribusi tegangan dan daerah kritis yang terjadi pada cover CVT. Setelah dilakukan pengujian didapatkan tegangan von mises maksimum cover standart dengan beban $75 \mathrm{~kg}$ sebesar $34751 \mathrm{~N} / \mathrm{m}^{2}$ dan tegangan minimum sebesar 0,014258 $\mathrm{N} / \mathrm{m}^{2}$, untuk beban $5 \mathrm{~kg}$ sebesar $2316.7 \mathrm{~N} / \mathrm{m}^{2}$ dan tegangan minimum sebesar $0,00095116 \mathrm{~N} / \mathrm{m}^{2}$. Untuk cover CVT modifikasi dengan beban $75 \mathrm{~kg}$ sebesar $21171 \mathrm{~N} / \mathrm{m}^{2}$ dan tegangan minimum sebesar $0,0011148 \mathrm{~N} / \mathrm{m}^{2}$, untuk beban $5 \mathrm{~kg}$ sebesar $1411.4 \mathrm{~N} / \mathrm{m}^{2}$ dan tegangan minimum sebesar $0,00074396 \mathrm{~N} / \mathrm{m}^{2}$.
\end{abstract}

Kata Kunci:, Analisis Tegangan Statik, , Tegangan Von Mises, Faktor Keamanan.

\begin{abstract}
Cover CVT is a component that has an important role of metic motorcycle because it has the function of protecting CVT components from impact, dirt, water or objects that can damage CVT components. Therefore, a static voltage analysis of the CVT cover design on the 1.0 generation of the vehicle's electric vehicle ganesha design using CVT Yamaha nuvo cover is used as the material for the CVT cover design development using ansys 14.5 software with a maximum load ratio of $75 \mathrm{~kg}$ and an initial loading of $5 \mathrm{~kg}$. The purpose of this research is to know the distribution of stress and critical area that happened on CVT cover. After the test, the maximum von mises stress standard cover with 75 $\mathrm{kg}$ load is $34751 \mathrm{~N} / \mathrm{m} 2$ and the minimum voltage is $0.014258 \mathrm{~N} / \mathrm{m} 2$, for $5 \mathrm{~kg}$ load is $2316.7 \mathrm{~N} / \mathrm{m} 2$ and the minimum voltage is $0.00095116 \mathrm{~N} / \mathrm{m} 2$. For cover CVT modification with $75 \mathrm{~kg}$ load of $21171 \mathrm{~N} / \mathrm{m} 2$ and minimum voltage of $0,0011148 \mathrm{~N} / \mathrm{m} 2$, for $5 \mathrm{~kg}$ load of $1411.4 \mathrm{~N} / \mathrm{m} 2$ and minimum voltage of $0.00074396 \mathrm{~N} / \mathrm{m} 2$.
\end{abstract}

Keywords :, Static Voltage Analysis,, Von Mises Voltage, Security Factor 
JJTM, Vol. 5 No. 3, November 2017

\section{PENDAHULUAN}

Continuously Variable Transmission (CVT) merupakan bagian dari sepeda motor yang dibuat menyatu pada crankcase / bak mesin sepeda motor metic, Continuously Variable Transmission (CVT) adalah sebuah transmisi yang dapat mengubah kecepatan dengan jumlah rasio roda gigi tak terbatas dengan efektif antara nilai maksimum dan minimum. Hal ini kontras dengan transmisi mekanis lainnya yang menawarkan sejumlah gigi rasio tetap. Fleksibilitas CVT memungkinkan poros input untuk mempertahankan kecepatan konstan selama rentang output kecepatan. CVT dapat memberikan penghematan bahan bakar yang lebih baik daripada transmisi manual dengan memungkinkan mesin untuk berjalan pada perubahan yang paling efisien per menit (RPM) untuk berbagai kecepatan kendaraan. Hal ini juga dapat digunakan untuk membangun sistem pemulihan energi kinetik. Sebagai alternatif transmisi ini dapat digunakan untuk memaksimalkan kinerja kendaraan. Desain CVT pada masingmasing merek motor berbeda-beda namun memiliki prinsip kerja yang sama, yang dapat membedakan CVT dari masingmasing merek motor adalah dari bentuk atau desain cover CVT atau yang lebih di kenal dengan sebutan cover box CVT kendaraan tersebut, terjadi banyak kemajuan dalam pembuatan kendaraan begitu pula dalam pembuatan cover CVT, baik kemajuan dalam proses pembuatan ataupun pengembangan bahan baku pembuatan crankcase mesin tersebut. Pembuatan cover CVT sudah menggunakan sotfware sehingga kemungkinan terjadinya human error dan biaya yang dikeluarkan untuk membuatnya juga relatif sedikit. Hal ini dikarenakan tidak perlunya dilakukan pembuatan cover CVT yang sesungguhnya untuk mengetahui keamanan dari cover CVT kendaraan yang akan dibuat, melainkan dengan bantuan software saja akan mendapatkan hasil yang akurat. Dalam pembuataan desain cover CVT kendaraan yang menggunakan software kita tidak perlu lagi menguji bahan yang akan digunakan dalam membuat cover CVT kendaraan karena kekuatan bahan tersebut sudah tercantum pada software. Selain itu, kita tidak perlu membuat cover CVT sebenarnya untuk mengetahui kekuatan dari cover CVT tersebut. Hal ini dikarenakan dalam software tersebut kita dapat menguji desain cover CVT yang kita buat dan mengetahui kekuatannya secara akurat.

Dengan software, peneliti akan lebih mudah untuk mengetahui kekuatan dari cover CVT yang diteliti. Oleh karena itu, untuk mengetahui kekuatan statik cover CVT. Peneliti akan menganalisa tegangan statik pada cover CVT Electric vehicles Ganesha 1.0 Generasi 1 yang menggunakan CVT sepeda motor Yamaha Nouvo. Dalam penelitian tugas akhir ini digunakan software Ansys 14.5 sebagai sarana untuk menganalisa tegangan statik yang terjadi pada cover CVT dan memilih logam aluminium sebagai bahan uji desain cover CVT. Crankcase atau yang dikenal dengan bak mesin merupakan tempat dudukan komponen egnine dan casis untuk jenis motor metik, crankcase dan cover box CVT secara umum terbuat dari jenis logam yang berbeda, baik itu jenis logam besi klabu, besi perak, baja dan paduan antara besi dan aluminium, alasan bahan ini dipilih dalam produksi adalah selain karna kuat bahan ini juga murah, yang mampu ikut menekan biaya produksi. Di dalam dunia otomotif bahan yang digunakan dituntut agar memiliki criteria bobot yang ringan serta kuat untuk menahan gerakan komponen-komponen mesin, oleh karna itu pengembangan bahan terus dilakukan demi mendapatkan bahan yang diinginkan, agar dapat meningkatkan efisiensi penggunaa bahan bakar dan performa kerja mesin. Dilihat dari permasalahan tersebut peneliti ingin menguji bahan aluminium sebagai

Jurnal Pendidikan Teknik Mesin Undiksha | 28 
bahan baru pengembangan desain cover CVT pada rancangan kendaraan electric vehicles ganesha 1.0 generasi, karna aluminium memiliki bobot yang lebih ringan dari baja dan besi, dalam pengujian ini peneliti ingin meningkatkan efisiensi penggunaan arus listik dan meningkatkan performan putaran mesin.

Software pengujian yang digunakan adalah software pengujian static, Software Ansys adalah sebuah software yang mampu menyelesaikan persoalan-persoalan elemen dari pemodelan sampai analisis. Ansys ini banyak digunakan untuk membantu dalam penelitian yang berbentuk statis maupun dinamis, analisis struktural, perpindahan panas, dinamika fluida, dan elektromagnetik untuk para engineer. Selain itu, Ansys memiliki tampilan prototipe dalam bentuk tiga dimensi yang bisa ditampilkan di layar komputer sehingga orang yang awam di bidang teknik pun dapat mengetahui dengan mudah.

\section{KAJIAN TEORI}

\section{Pengertian CVT}

Sistem Continously Variable

Transmission (CVT), adalah sistem otomatik yang dipasang pada beberapa tipe sepeda motor saat ini. Sistem ini menghasilkan perbandingan reduksi secara otomatis sesuai dengan putaran mesin, sehingga pengendara terbebas dari keharusan memindah gigi sehingga lebih nyaman dan santai. Sistem CVT banyak kita jumpai pada motor metik, seperti yamaha mio,honda vario, suzuki spin dan lainya. Mekanisme $V$ belt tersimpan dalam ruangan yang dilengkapi dengan sistim pendingin untuk mengurangi panas yang timbul karena gesekan sehingga bisa tahan lebih lama. Sistim aliran pendingin $V$-belt ini dibuat sedemikian rupa sehingga terbebas dari kotoran / debu dan air. Lubang pemasukan udara pendingin terpasang lebih tinggi dari as roda untuk menghindari masuknya air saat sepeda motor berjalan di daerah banjir. Kelebihan Utama Sistim CVT. Sistim CVT dapat memberikan perubahan kecepatan dan perubahan torsi dari mesin ke roda belakang secara otomatis. Dengan perbandingan ratio yang sangat tepat tanpa harus memindah gigi, seperti pada motor transmisi konventional. Dengan sendirinya tidak terjadi hentakan yang biasa timbul pada pemindahan gigi pada mesin-mesin konvensional. Perubahan kecepatan sangat lembut dengan kemampuan mendaki yang baik. Sistim CVT terdiri pulley primary dan pulley secondary yang dihubungkan dengan -belt.

\section{Ansys 14.5}

Ansys 14.5 adalah sebuah software yang mampu menyelesaikan persoalanpersoalan elemen dari pemodelan sampai analisis. Ansys ini banyak digunakan untuk membantu dalam penelitian yang berbentuk statis maupun dinamis, analisis struktural, perpindahan panas, dinamika fluida, dan elektromagnetik untuk para engineer.

Selain itu, Ansys 14.5 memiliki tampilan prototipe dalam bentuk tiga dimensi yang bisa ditampilkan di layar komputer sehingga orang yang awam di bidang teknik pun dapat mengetahui dengan mudah. Kemudahan inilah yang membuat banyak peneliti menyelesaikan permasalahannya dengan menggunakan Ansys 14.5. Hal ini dikarenakan peneliti lebih cepat dalam menyelesaikan permasalahan dengan hanya membuat model tiga dimensi benda yang akan dianalisis dan langsung melakukan analisis sehingga hasilnya langsung dapat diketahui. Ansys 14.5 dalam prosesnya terbagi menjadi 3 tahapan, yaitu :

1. Engineering Data

Dalam engineering data ini kita bisa memilih bahan/material yang digunakan benda yang akan dianalisis. Biasanya bahan/material ini sudaah disediakan di dalam software ini, namun jika bahan yang kita akan gunakan belum ada dalam software kita bisa langsung menambahkan bahan tersebut dengan menginputkan kekuatan bahan tersebut. Berikut ini adalah 
JJTM, Vol. 5 No. 3, November 2017

tampilan dalam engineering data seperti pada gambar 13 Engineering Data.

\section{Geometry}

Geometry disini dimaksudkan adalah proses pembuatan model dari benda yang akan dianalisis atau bisa dibilang tempat untuk menggambar benda yang akan dianlisis. Dalam geometry ini ada banyak toolbar yang bisa membantu dalam proses pembuatan geometry benda, seperti draw, modify, dimensions, constraints, extrude, revolve, sweep, blend, champer, slice, skin/loft, thin/surface, dan lain sebagainya. Berikut ini adalah tampilan dalam geometry seperti pada gambar.

3. Model

Setelah selesai membuat geometry benda dilanjutkan dengan memberikan model pada benda tersebut. Dalam model terdapat dua proses yaitu statistic structural dan solution.

Statistic structural adalah proses untuk menambahkan analisis yang akan diberikan pada benda. Analisis ini bisa berupa pressure, hydrostatic pressure, force, moment, fixed support, displacement, dan lain sebagainya.

Pada solution kita akan mengetahui informasi dari analisis yang kita lakukan. Informasi analisis ini berupa deformation, strain, stress, energy, dan lain sebagainya.

\section{Kerangka Berpikir}

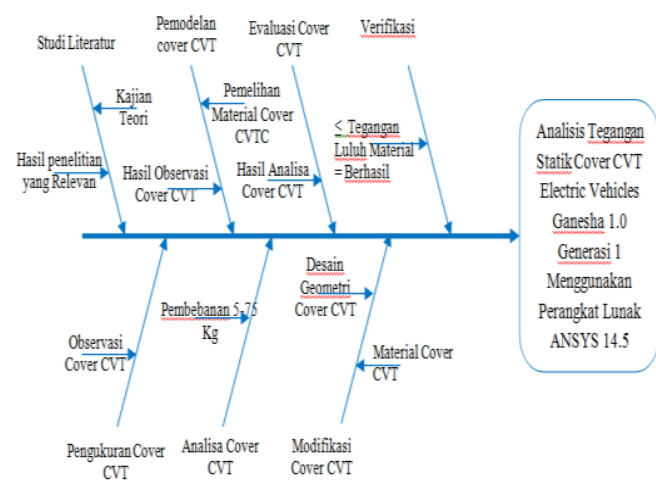
Gambar
2.7 Diagram
Fisbon Penelitian Analisis Tegangan Statik Cover CVT

\section{METODE}

\section{Jenis Penelitian}

Jenis penelitian yang dilakukan dalam penelitian ini tergolong true eksperiment atau penelitian sebenarnya. Disebut true eksperiment atau penelitian sebenarnya karena dalam eksperimen ini tidak semua variabel (gejala) yang muncul dapat diatur dan dikontrol secara ketat. Dalam penelitian ini akan diteliti hasil pengembangan desain cover CVT Pada Rancangan Kendaraan Electric Vehicles Ganesha 1.0 Generasi 1

\section{Rancangan penelitian}

Penelitian ini diawali dengan studi literatur mengenai penelitian-penelitian yang telah ada dan berbagai teori penunjang yang berkaitan dengan analisis tegangan statik. Setelah mendapatkan studi literatur yang diperlukan, dilanjutkan pengukuran cover CVT dan pengumpulan data-data cover CVT yang diperlukan. Setelah data yang diperlukan didapat, terlebih dahulu dilakukan penginputan material yang digunakan dalam ansys 14.5 sebelum dilanjutkan dengan pemodelan /mendesain geometri cover CVT sesuai dengan data hasil pengukuran geometri cover CVT yang diperoleh pada software Ansys 14.5. Kemudian dilanjutkan dengan melakukan analisis statik pada cover CVT yang sudah dibuat dengan menguji tanpa pembebanan dan dengan beban yang maksimal $(75 \mathrm{Kg})$. dari hasil analisis cover CVT standart, jika hasil tegangan static lebih kecil dari tegangan luluh material maka penelitian ini dapat dilanjutkan, sebaliknya jika lebih besar tegangan luluh material maka akan kembali dilakukan pengukuran bentuk geometri cover CVT Setelah itu, dilakukan modifikasi pada cover CVT dengan melihat tempat terjadinya beban terbesar sehingga dapat memperkecil beban yang terjadi pada cover CVT tersebut. Kemudian dilakukan analisis pada cover CVT modifikasi yang di berikan beban maksimal sebesar $75 \mathrm{~kg}$ dan nol pembebanan. Dari hasil analisis, jika tegangan static cover CVT modifikasi lebih kecil dari tegangan luluh material dan tegangan static cover CVT standar maka 
JJTM, Vol. 5 No. 3, November 2017

penelitian di katakana berhasil, sebaliknya jika tegangan static cover CVT lebih besar dari tegangan luluh material dan tegangan static cover CVT standar maka akan dilakukan modifikasi cover CVT kembali. Dari penjelasan diatas, maka dapat digambarkan flow chart dari penelitian analisis statik pada cover CVT yang akan dilakukan sebagai berikut.

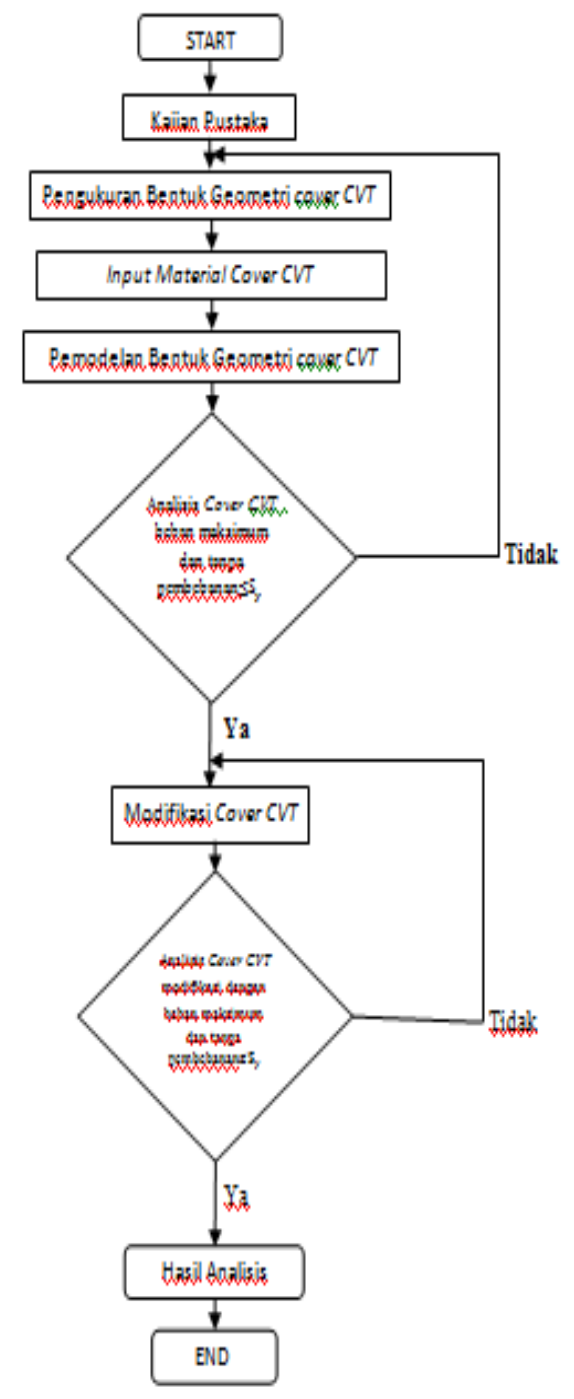

Gambar 3.2. Flow Chart Analisis Tegangan Statik Pada Cover CVT

\section{Tempat dan Waktu Penelitian}

Penelitian analisis statik ini dilakukan di Laboratorium CNC Jurusan Pendidikan Teknik Mesin Fakultas Teknik dan Kejuruan Universitas Pendidikan Ganesha. Waktu penelitian dilaksanakan dalam jangka waktu enam (6) bulan yaitu mulai dari bulan Mei 2017 sampai Oktober 2017.

\section{Alat dan Bahan}

Alat

Peralatan yang digunakan dalam penelitian ini adalah sebagai berikut :

a. Laptop Asus x451 lb, cor i5 yang berisi software ansys 14.5

Laptop digunakan untuk membuat desain cover CVT yang akan dianalisis dalam bentuk 3 dimensi di software ansys 14.5 berdasarkan hasil pengukuran geometri cover CVT yang telah dilakukan. Serta melakukan analisis cover CVT yang sudah dibuat dalam software ansys 14.5 sehingga diketahui tegangan yang paling besar pada cover CVT.

b. Jangka sorong Jangka sorong digunakan untuk mengukur geometri cover CVT yang diteliti, dimana cover CVT yang diteliti memiliki bentuk bulat dan lubang pada desain cover CVT sehingga jangka sorong ini digunakan untuk mengukur diameter dan kedalaman dari desain cover CVT tersebut.

c. Meteran

Meteran disini digunakan untuk mengukur geometri cover CVT yang berbentuk persegi.

d. Buku dan Pulpen

Buku dan pulpen digunakan untuk mencatat hasil pengukuran geometri

Bahan cover CVT yang diteliti.

Bahan yang digunakan dalam penelitian ini adalah sebagai berikut :

a. Sketsa Pengembangan desain cover CVT Motor Yamaha Nouvo, adalah 
bahan yang akan di uji statik pada software ansys 14.5 .

\section{Pengumpulan Data Instrumen Penelitian}

Instrumen yang digunakan dalam penelitian ini adalah observasi. Observasi dalam sebuah penelitian diartikan sebagai pemusatan perhatian terhadap objek dengan melibatkan seluruh indera untuk mendapatkan data. Jadi observasi merupakan pengamatan langsung denga $\mathrm{n}$ menggunakan penglihatan, penciuman, pendengaran, perabaan, atau kalau perlu dengan pengecapan. Dalam penelitian ini akan dilakukan observasi terhadap pengembangan desain CVT Electric vehicles Ganesha 1.0 Generasi 1 yang menggunakan CVT Yamaha Nouvo untuk mengetahui geometri dari cover CVT yang diteliti untuk menunjang penelitian analisis statik ini.

\section{Metode Pengumpulan Data}

Metode atau teknik pengumpulan data dalam penelitian ini dilakukan melalui tahapan-tahapan berikut :

1. Pengukuran geometri Cover CVT

2. Pemodelan atau membuat desain cover CVT pada software ansys 14.5 sesuai dengan data yang diperoleh dari pengukuran geometri cover CVT

3. Melakukan analisis statik cover CVT dengan software ansys 14.5 sampai memperoleh hasil analisis statik.

4. Memodifikasi desain cover CVT pada software ansys 14.5

5. Melakukan analisis statik cover CVT modifikasi dengan software ansys 14.5 sampai memperoleh hasil analisis statik.

\section{Metode Analisis Data}

Metode analisis data yang digunakan dalam penelitian ini yaitu metode elemen hingga. Metode elemen hingga ini banyak diterapkan dalam bidang struktur untuk menyelesaikan persoalan statik, dinamik, linear maupun non-linear. Selain itu, metode ini juga diterapkan dalam bidang perpindahan panas, aliran fluida, medan magnet, dan persoalan lainnya.

Metode Elemen Hingga (Finite Element Method) adalah sebuah metode penyelesaian permasalahan teknik yang menggunakan pendekatan dengan membagi-bagi (diskritisasi) benda yang akan dianalisis ke dalam bentuk elemenelemen yang berhingga yang saling berkaitan satu sama lain.

Metode elemen hingga ini merupakan cara numerik untuk menyelesaikan masalah dalam ilmu rekayasa dan matematika fisik. Hal ini terbukti karena metode ini menjadi solusi yang digunakan untuk memperoleh penyelesaian bagi sistem dengan geometri, beban, dan material yang kompleks.

\section{Hasil Penelitian \\ Analisa Cover CVT}

Data hasil penelitian di dapat dari analisis yang di lakukan pada cover CVT rancangan kendaraan electric vehicles ganesha 1.0 generasi 1 dalam software ansys 14.5 . dalam mendapatkan hasil penelitian, peneliti terlebih dahulu membuat desain cover CVT pada software ansys 14.5 sesuai dengan hasil pengukuran geometri cover CVT yang telah dilakukan. Adapun desain cover CVT yang telah di buat dalam soft ware ansys 14.5 dapat dilihat pada gambar 4.1 


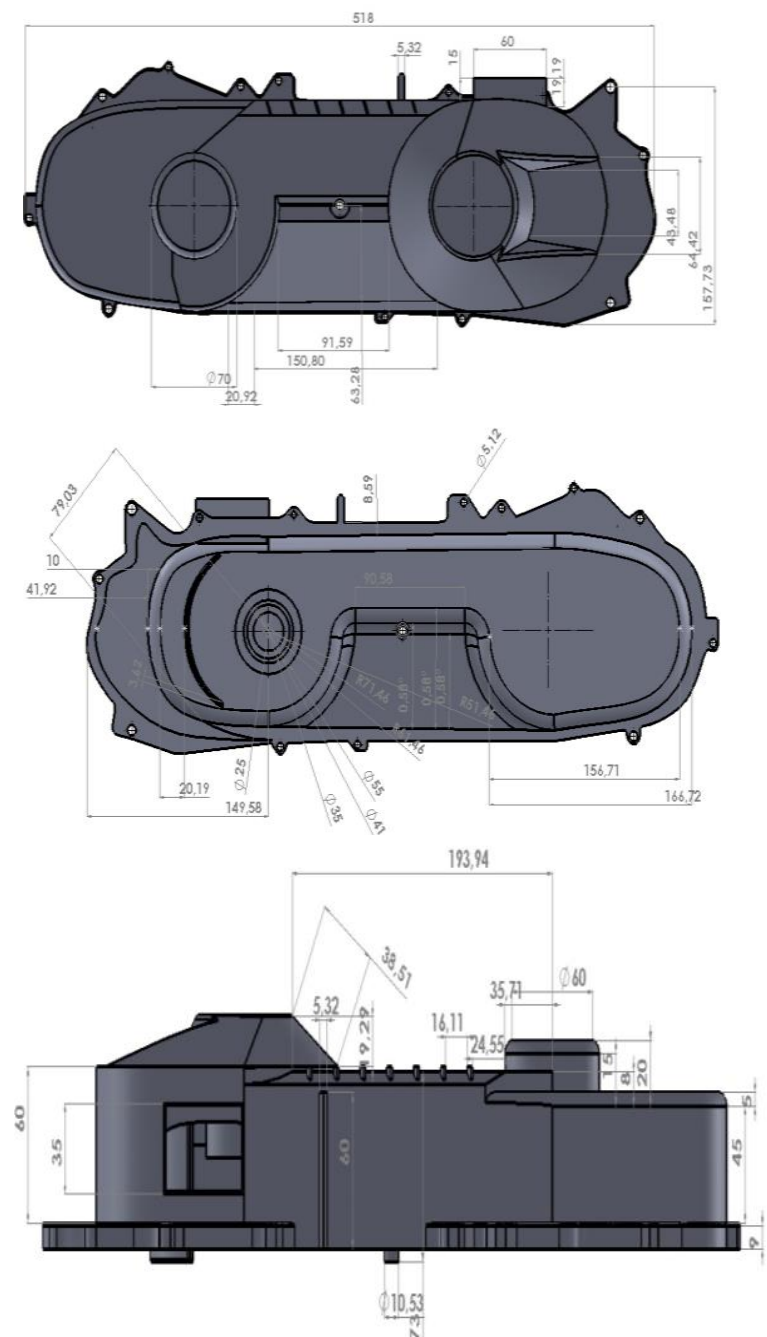

Desain cover CVT yang telah dibuat seperti pada gambar 4.1 akan di analisis dalam software ansys 14.5 dengan cara memberikan beban maksimal sebesar 75 $\mathrm{kg}$ dan pembebanan awal sebesar $5 \mathrm{~kg}$ yang akan di berikan secara merata pada permukaan cover CVT sehingga akan di ketahui distribusi tegangan yang akan terjadi pada cover CVT.

Berikut ini adalah hasil analisis yang telah dilakukan pada cover CVTakibat di berikan pembebanan maksimum sebesar $75 \mathrm{~kg}$ bisa dilihat pada gambar.

\section{Hasil Analisis Tegangan Statik Pada Cover CVT Dengan Beban Maksimal Sebesar 75 kg}

Distribusi tegangan static pada cover CVT dengan beban maksimal sebesar $75 \mathrm{~kg}$

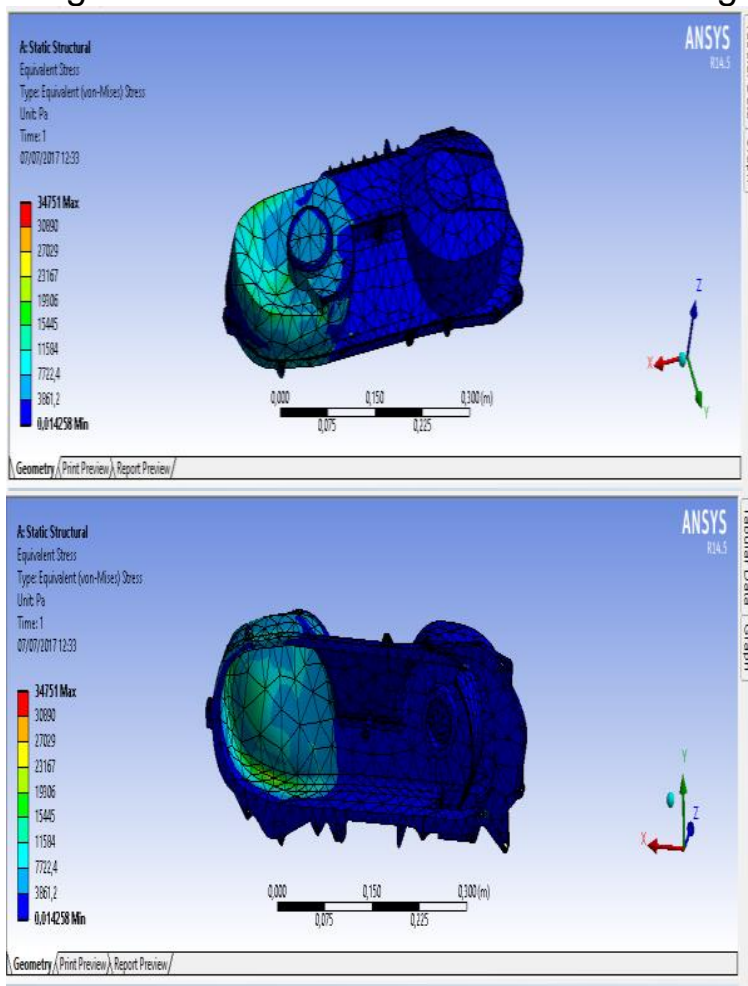

Hasil tegangan ( von misses stress) maksimum di tunjukkan dengan warna merah sebesar $34751 \mathrm{~N} / \mathrm{m}^{2}$ dan tegangan ( von misses stress) minimum di tunjukkan dengan warna biru sebesar $0,014258 \mathrm{~N} / \mathrm{m}^{2}$ dengan beban yang di berikan sebesar 75 $\mathrm{kg}$. maka berdasarkan tegangan luluh minimum material yang di gunakan yaitu Aluminium sebesar $5,500 \mathrm{~N} / \mathrm{m}^{2}$ dapat di pastikan struktur tersebut mampu menahan beban yang di berikan.

Dari hasil analisis, dapat dicari factor keamanan ( factor of safety) dari cover CVT yang di berikan beban maksimum sebesar $75 \mathrm{~kg}$ yang dapat di rumuskan sebagai berikut.

$$
\begin{gathered}
\eta=\frac{\mathrm{S}_{\mathrm{y}}}{\sigma_{\mathrm{e}}} \\
=\frac{5.500 \mathrm{~N} / \mathrm{m}^{2}}{34751 \mathrm{~N} / \mathrm{m}^{2}} \\
=0.158
\end{gathered}
$$

Jurnal Pendidikan Teknik Mesin Undiksha | 33 
1. Hasil Analisis Tegangan Statik Cover CVT Dengan Pembebanan Awal Sebesar $5 \mathrm{~kg}$

Distribusi tegangan static pada cover CVT dengan pembebanan awal

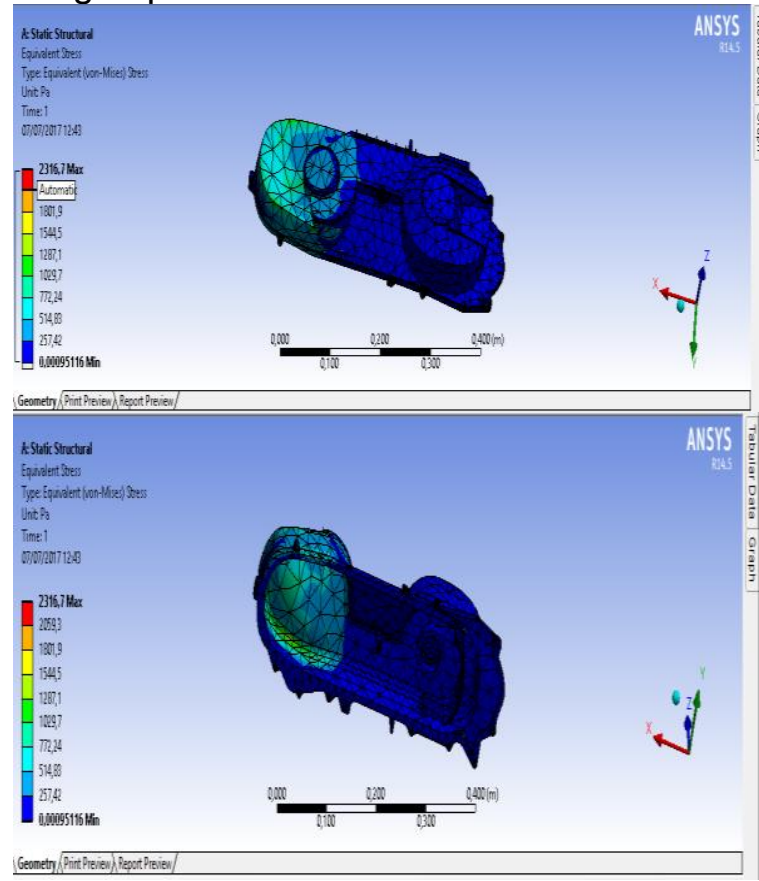

Hasil tegangan ( von misses stress) maksimum di tunjukkan dengan warna merah sebesar $2316.7 \mathrm{~N} / \mathrm{m}^{2}$ dan tegangan ( von misses stress) minimum di tunjukkan dengan warna biru sebesar 0.00095116 $\mathrm{N} / \mathrm{m}^{2}$ dengan beban yang di berikan sebesar $5 \mathrm{~kg}$. Maka berdasarkan tegangan luluh minimum material yang di gunakan yaitu Aluminium sebesar $5,500 \mathrm{~N} / \mathrm{m}^{2}$ dapat di pastikan struktur tersebut mampu menahan beban yang di berikan.

Dari hasil analisis, dapat dicari factor keamanan ( factor of safety) dari cover CVT yang di berikan beban maksimum sebesar $5 \mathrm{~kg}$ yang dapat di rumuskan sebagai berikut.

$$
\begin{gathered}
\eta=\frac{S_{y}}{\sigma_{e}} \\
=\frac{5.500 \mathrm{~N} / \mathrm{m}^{2}}{2316.7 \mathrm{~N} / \mathrm{m}^{2}}
\end{gathered}
$$

$$
=2.374
$$

Modifikasi Cover CVT ke 1

Setelah mengetahui distribusi tegangan static pada cover CVT, di ketahui tegangan terbesar terjadi pada bagian depan cover CVT, selanjutnya setelah diketahui distribusi tegangan yang terjadi pada cover CVT baru dilakukan modifikasi. Dimana modifikasi dilakukan untuk memperkecil tegangan static yang terjadi, peneliti melakukan beberapa modifikasi pada cover CVT. Berikut adalah modifikassi yang dilakukan :

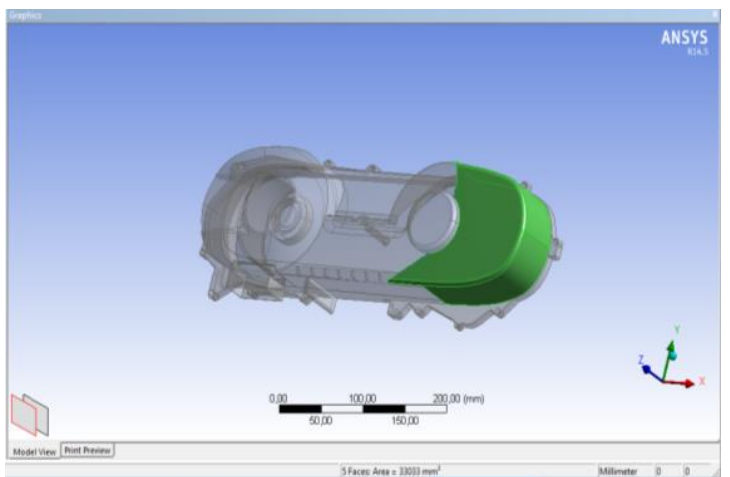

Modifikasi yang dilakukan adalah dengan merubah model pada bagian depan seperti gambar diatas setelah melakukan modifikasi pada desain cover CVT maka dilakukanlah pengujian ulang pada cover modifikasi seperti gambar di atas sehingga akan diketahui distribusi tegangan yang terjadi pada cover CVT modifikasi dengan pengujian dengan pembebanan maksimal sebesar $75 \mathrm{~kg}$ dan dengan beban awal sebesar $5 \mathrm{~kg}$, dan berikut adalah hasil dari analisis tegangan static pada cover CVT modifkasi:

Hasil Analisis Tegangan Satik Cover CVT Modifikasi Dengan Pembebanan Maksimal Sebesar $75 \mathrm{~kg}$.

Distribusi tegangan static terjadi pada cover CVT modifikasi akibat diberikan pembebanan sebesar $75 \mathrm{~kg}$. 


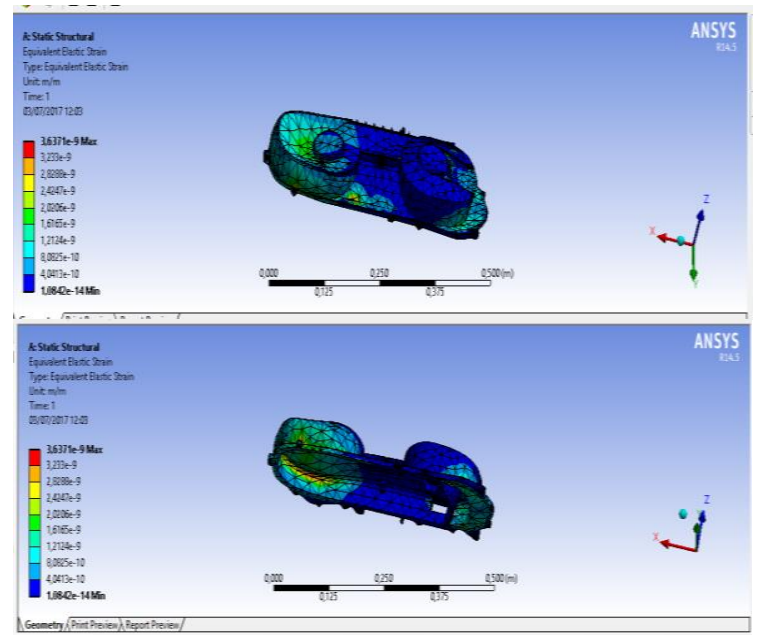

Hasil tegangan ( von misses stress) maksimum di tunjukkan dengan warna merah sebesar $3,6371 \times-10^{9} \mathrm{~N} / \mathrm{m}^{2}$ dan tegangan ( von misses stress) minimum di tunjukkan dengan warna biru sebesar $1,0842 \times-10^{14} \mathrm{~N} / \mathrm{m}^{2}$ dengan beban yang di berikan sebesar $75 \mathrm{~kg}$. maka berdasarkan tegangan luluh minimum material yang di gunakan yaitu Aluminium sebesar 5,500 $\mathrm{N} / \mathrm{m}^{2}$ dapat di pastikan struktur tersebut mampu menahan beban yang di berikan.

Dari hasil analisis, dapat dicari factor keamanan ( factor of safety) dari cover CVT yang di berikan beban maksimum sebesar $75 \mathrm{~kg}$ yang dapat di rumuskan sebagai berikut.

$$
\begin{gathered}
\eta=\frac{S_{\mathrm{y}}}{\sigma_{\mathrm{e}}} \\
=\frac{5.500 \mathrm{~N} / \mathrm{m}^{2}}{3,6371 \times-10^{9} \mathrm{~N} / \mathrm{m}^{2}} \\
=1,512 \times-10^{9}
\end{gathered}
$$

Hasil Analisis Tegangan Satik Cover CVT Modifikasi Dengan Pembebanan Awal.

Distribusi tegangan static terjadi pada cover CVT modifikasi akibat pembebanan awal

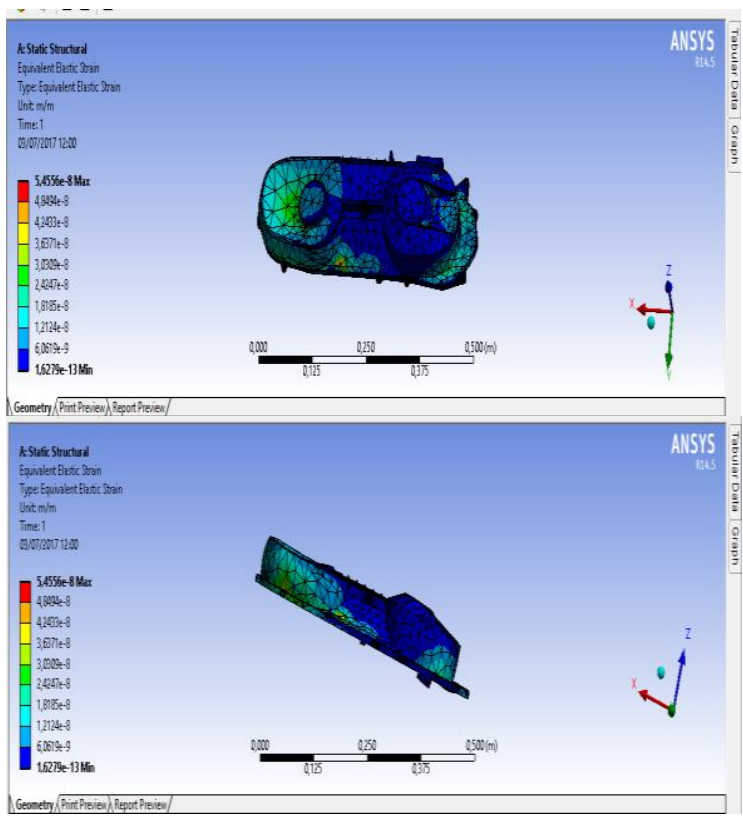

Hasil tegangan ( von misses stress) maksimum di tunjukkan dengan warna merah sebesar $5,4556 \times-10^{8} \mathrm{~N} / \mathrm{m}^{2}$ dan tegangan (von misses stress) minimum di tunjukkan dengan warna biru sebesar $1,6279 \times-10^{13} \mathrm{~N} / \mathrm{m}^{2}$ dengan beban yang di berikan sebesar $5 \mathrm{~kg}$. maka berdasarkan tegangan luluh minimum material yang di gunakan yaitu Aluminium sebesar 5,500 $\mathrm{N} / \mathrm{m}^{2}$ dapat di pastikan struktur tersebut mampu menahan beban yang di berikan.

Dari hasil analisis, dapat dicari factor keamanan ( factor of safety) dari cover CVT yang di berikan beban maksimum sebesar $5 \mathrm{~kg}$ yang dapat di rumuskan sebagai berikut.

$$
\begin{gathered}
\eta=\frac{\mathrm{S}_{\mathrm{y}}}{\sigma_{\mathrm{e}}} \\
=\frac{5.500 \mathrm{~N} / \mathrm{m}^{2}}{5,4556 \times-10^{8} \mathrm{~N} / \mathrm{m}^{2}} \\
=100 \times-10^{8}
\end{gathered}
$$

\section{Modifikasi Cover CVT ke 2}

Hasil Analisis Tegangan Satik Cover CVT Modifikasi Dengan Pembebanan Awal Sebesar $5 \mathrm{~kg}$

Jurnal Pendidikan Teknik Mesin Undiksha | 35 
Distribusi tegangan static terjadi pada cover CVT modifikasi akibat diberikan pembebanan sebesar $5 \mathrm{~kg}$

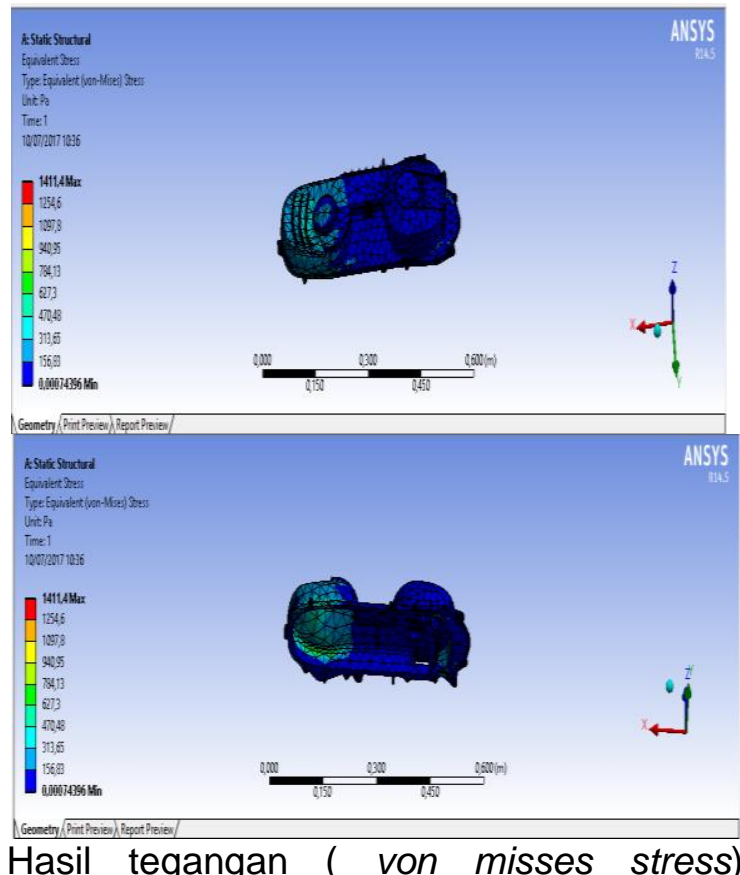

maksimum di tunjukkan dengan warna merah sebesar $1411,4 \mathrm{~N} / \mathrm{m}^{2}$ dan tegangan ( von misses stress) minimum di tunjukkan dengan warna biru sebesar 0,00074396 $\mathrm{N} / \mathrm{m}^{2}$ dengan beban yang di berikan sebesar $75 \mathrm{~kg}$. maka berdasarkan tegangan luluh minimum material yang di gunakan yaitu Aluminium sebesar 5,500 $\mathrm{N} / \mathrm{m}^{2}$ dapat di pastikan struktur tersebut mampu menahan beban yang di berikan.

Dari hasil analisis, dapat dicari factor keamanan ( factor of safety) dari cover CVT yang di berikan beban maksimum sebesar $75 \mathrm{~kg}$ yang dapat di rumuskan sebagai berikut.

$$
\begin{gathered}
\eta=\frac{\mathrm{S}_{\mathrm{y}}}{\sigma_{\mathrm{e}}} \\
=\frac{5.500 \mathrm{~N} / \mathrm{m}^{2}}{1411,4 \mathrm{~N} / \mathrm{m}^{2}} \\
=3.896
\end{gathered}
$$

\section{Hasil Analisis Tegangan Satik Cover CVT Modifikasi Dengan Pembebanan Maksimal Sebesar $75 \mathrm{~kg}$}

Distribusi tegangan static terjadi pada cover CVT modifikasi akibat pembebanan nol

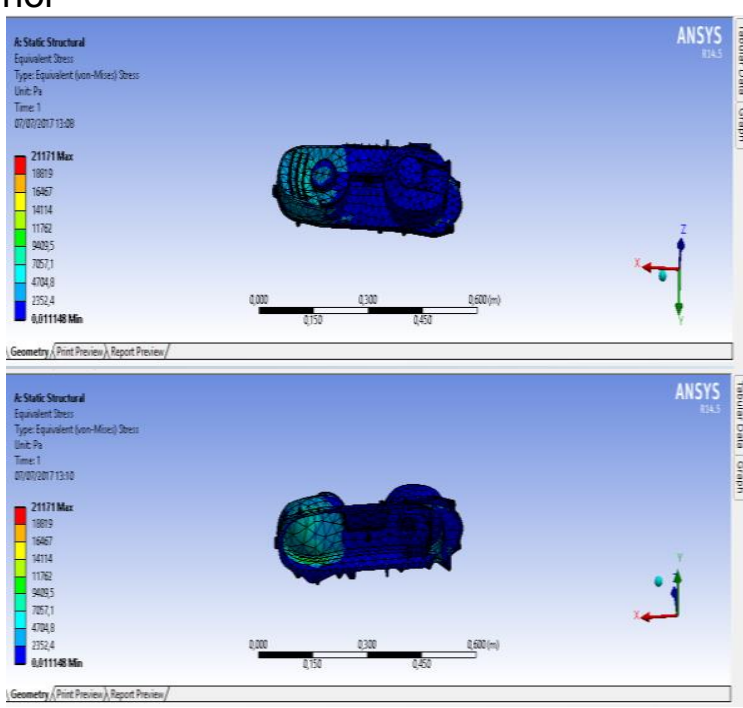

Hasil tegangan ( von misses stress) maksimum di tunjukkan dengan warna merah sebesar $21171 \mathrm{~N} / \mathrm{m}^{2}$ dan tegangan ( von misses stress) minimum di tunjukkan dengan warna biru sebesar $0,011148 \mathrm{~N} / \mathrm{m}^{2}$ dengan beban yang di berikan sebesar 5 $\mathrm{kg}$. Maka berdasarkan tegangan luluh minimum material yang di gunakan yaitu Aluminium sebesar $5,500 \mathrm{~N} / \mathrm{m}^{2}$ dapat di pastikan struktur tersebut mampu menahan beban yang di berikan.

Dari hasil analisis, dapat dicari factor keamanan ( factor of safety) dari cover CVT yang di berikan beban maksimum sebesar $5 \mathrm{~kg}$ yang dapat di rumuskan sebagai berikut.

$$
\begin{gathered}
\eta=\frac{S_{y}}{\sigma_{e}} \\
=\frac{5.500 \mathrm{~N} / \mathrm{m}^{2}}{21171 \mathrm{~N} / \mathrm{m}^{2}} \\
=0,259
\end{gathered}
$$




\section{Pembahasan Komperatif Cover CVT dan Cover CVT Modifikasi}

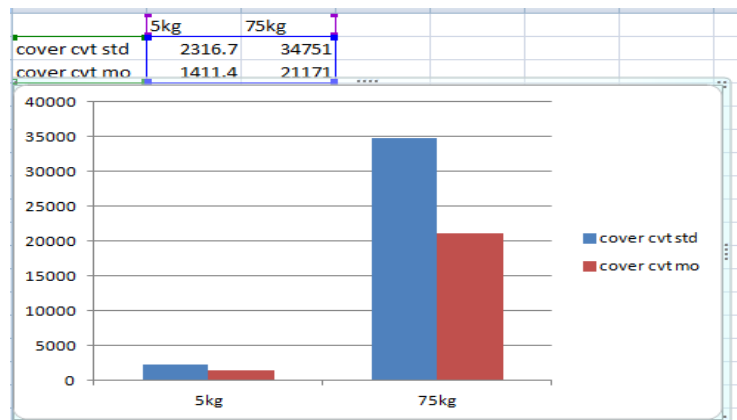

Grafik 4.1.8 Komperatif Tegangan Maksimum Cover CVT dan Cover CVT Modifikasi

Dari grafik 4.1.8 diketahui bahwa setelah Cover CVT dan Cover CVT modifikasi dianalisis dengan beban maksimum sebesar $75 \mathrm{~kg}$ dan beban 0 ( $5 \mathrm{~kg}$ ). Hasil tegangan maksimum pada cover CVT mengalami penurunan setelah di modifikasi. Semakin kecil nilai tegangan yang didapat maka kekuatan cover CVT juga semakin baik.

\section{Komperatif Tegangan Minimum Cover CVT dan Cover CVT Modifikasi}

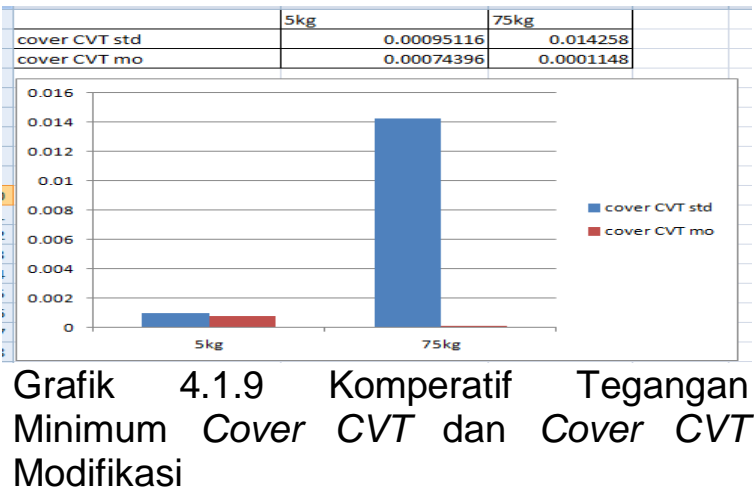

Dari grafik 4.1.9 diketahui bahwa setelah cover CVT dan cover CVT modifikasi dianalisis dengan beban sebesar $75 \mathrm{~kg}$ dan beban 0 ( $5 \mathrm{~kg})$. Hasil tegangan minimum pada cover CVT mengalami peningkatan setelah di modifikasi.

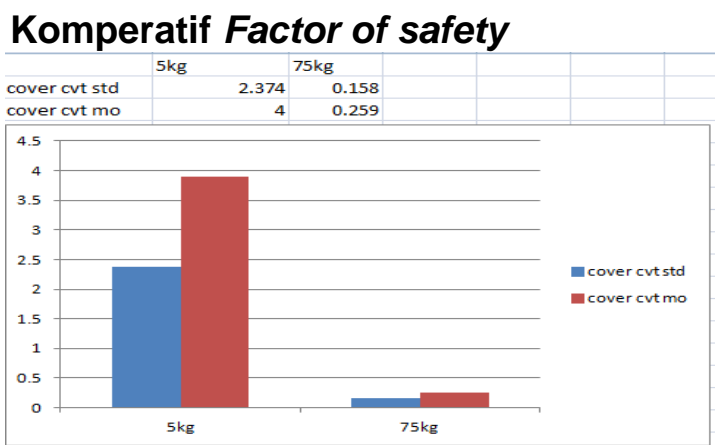

Grafik 4.1.10 Komperatif Factor of Safety

Dari grafik 4.1.10 diketahui bahwa setelah cover CVT dan cover CVT modifikasi dianalisis dengan beban sebesar $75 \mathrm{~kg}$ dan beban 0 ( $5 \mathrm{~kg}$ ). Faktor keamanan ( factor of safety) pada cover CVT mengalami peningkatan setelah mengalami modifikasi. Semakin besar faktor keamanan ( factor of safety) yang didapat maka kekuatan cover CVT juga semakin baik.

\section{DAFTAR PUSTAKA}

Berata, Wayan. Diktat Elemen Mesin I. Fakultas Teknologi Industri Institut Teknologi Sepuluh Nopember : Jurusan Teknik Mesin.

Firmansyah. 2012. "Analisis Statik Rangka Motor Hybrid Menggunakan Software Catia V5". Tugas Akhir (tidak diterbitkan).Jurusan Teknik Mesin, Universitas Gunadarma.

Joko Prasetyo, Apri. 2010. "Aplikasi Metode Elemen Hingga (MEH) Pada Struktur Rib Bodi Angkutan Publik. Jur. Teknik Mesin Fak. Teknik, Universitas Sebelas Maret

Mulyati. "Bahan Ajar Mekanika Bahan" Tegangan dan Regangan. Pertemuan I,II,III, hIm 1-20.

Studi Perancangan dan Rekayasa Sistem Jurusan Teknik Mesin Fakultas Teknik Universitas Brawijaya. Modul Finite Element Analysis.

Wabby purwo suseno 2011. Transmisiotomatis-sepeda-motor-cvt.

Andy ismawanto 2014, simulasi kekuatan material pada carabiner dengan variasi geometri, Jurnal ilmiah teknik mesin unlam vol.03 no. 1 pp 52-57 